\title{
Consecutive isocyanide-based multicomponent reactions: synthesis of cyclic pentadepsipeptoids
}

\author{
Angélica de Fátima S. Barreto ${ }^{1}$, Otilie E. Vercillo ${ }^{2}$, Ludger A. Wessjohann ${ }^{3}$ \\ and Carlos Kleber Z. Andrade*1
}

\section{Letter}

\section{Address:}

${ }^{1}$ Laboratório de Química Metodológica e Orgânica Sintética, Instituto de Química, Universidade de Brasília, CP 4478, 70910-970 Brasília-DF, Brazil, ${ }^{2}$ Faculdade UnB Planaltina, Área Universitária N ${ }^{\circ}$ 1, Vila Nossa Senhora de Fátima, Planaltina, 73300-000, Brasília, DF, Brazil and ${ }^{3}$ Department of Bioorganic Chemistry, Leibniz Institute of Plant Biochemistry, Weinberg 3, D-06120 Halle (Saale), Germany

\section{Email:}

Carlos Kleber Z. Andrade* - ckleber@unb.br

${ }^{*}$ Corresponding author

Keywords:

depsipeptoids; multicomponent reactions; Passerini reaction;

sansalvamide $A$; Ugi reaction
Beilstein J. Org. Chem. 2014, 10, 1017-1022.

doi:10.3762/bjoc. 10.101

Received: 13 February 2014

Accepted: 07 April 2014

Published: 05 May 2014

This article is part of the Thematic Series "Multicomponent reactions II" and is dedicated to Prof. Ronaldo A. Pilli on the occasion of his 60th anniversary.

Guest Editor: T. J. J. Müller

(C) 2014 Barreto et al; licensee Beilstein-Institut.

License and terms: see end of document.

\begin{abstract}
The synthesis of six cyclic depsipeptoids inspired by the natural depsipeptide sansalvamide A is described. An efficient and fast synthetic strategy was developed using a combination of consecutive isocyanide-based multicomponent reactions (Ugi and Passerini reactions). This methodology can be used to access a variety of cyclic oligodepsipeptoids.
\end{abstract}

\section{Introduction}

Peptoids are an interesting class of non-natural compounds that have recently received much attention due to their wide range of biological activities, which makes them attractive candidates for drug discovery [1-7]. This family of oligomers comprising poly- $N$-substituted glycines mimics the primary natural structure of peptides and exhibits greater proteolytic stability and increased cellular permeabilities in comparison to peptides [5-7]. A powerful synthetic tool for the preparation of a peptoid backbone is the Ugi four-component reaction (U-4CR) [8-14]. It has been demonstrated that the combination of multicomponent reactions with the use of microwave irradiation is able to efficiently produce complex molecules with a reduced number of steps and short reaction times [15-18].

Depsipeptides are polymeric natural compounds, analogues of peptides, being formed by amino acids and hydroxy acids linked together by amide and ester bonds. These natural products show promising biological activities, especially regarding their therapeutic potential in cancer treatment [19]. An example of a cyclic depsipeptide is sansalvamide A (San A, Figure 1) [20-29], which was isolated from a marine fungus (Fusarium spp.) [20] and exhibits antitumor activity against multiple 
cancer cell lines. It is cytotoxic against colon (HCT-116) [20,23,25,26], pancreatic (S2-013 and AsPC-1) [22,28,29], prostate (PC-3), breast (MDA-MB231) and melanoma cancers (WM-115) [24]. It has been reported that substitution of an ester group by an amide in the structure of a peptide provides an efficient way to evaluate the role of protein hydrogen bonding [3034]. Recent works have discovered that some analogues of San A inhibit Hsp 90, a key protein that enables many proteins involved in tumor progression [35-39].

The Passerini three-component reaction (P-3CR) allows an easy access to depsipeptides using a convergent approach. It has become a powerful tool in combinatorial synthesis [40-43] and can be used strategically for the synthesis of depsipeptoids. By analogy to peptides and peptoids, a depsipeptoid would be a peptoid bearing an ester group instead of an amide group. Differences between peptide, peptoid, depsipeptide and depsipeptoid structures are outlined in Figure 2.

\section{Results and Discussion}

In continuing our research on the synthesis of peptoids with potential pharmacological activity $[12,17,18,44,45]$ and using a fast and efficient microwave-assisted synthesis of peptoids $[15,17,18]$, we decided to carry out the synthesis of depsipep- toid analogues of San A based on a strategy developed in our groups for the synthesis of cyclic RGD pentapeptoids [44]. This strategy was adapted by a combination of microwave-assisted Ugi and Passerini reactions. It is also important to highlight that the synthesis of cyclic depsipeptoids had not been explored yet. In this paper, we describe the synthesis of six pentadepsipeptoid analogues of San A (Figure 3).

The synthetic route for the synthesis of cyclic pentadepsipeptoids via consecutive Ugi reactions allows only three side chains connected to three nitrogen atoms. The pentapeptide of San A has in its structure five side chains attached to the $\alpha$ carbon atoms: one isopropyl, one benzyl and three isobutyl groups. To generate the pentapeptoid analogues of San A, the side chain groups isobutyl, isopropyl and benzyl linked to the $\alpha$ carbon atom present in the peptide were moved to the nitrogen atoms. It was decided to keep at least one benzyl group in the structure of the peptoids and vary the isopropyl and isobutyl groups, thus maintaining a greater similarity with the structure of the San A depsipeptide.

The retrosynthetic analysis of the depsipeptoids (Scheme 1) shows that the proposed compounds can be achieved using a strategy based on: (a) formation of a peptoid via Ugi reaction;
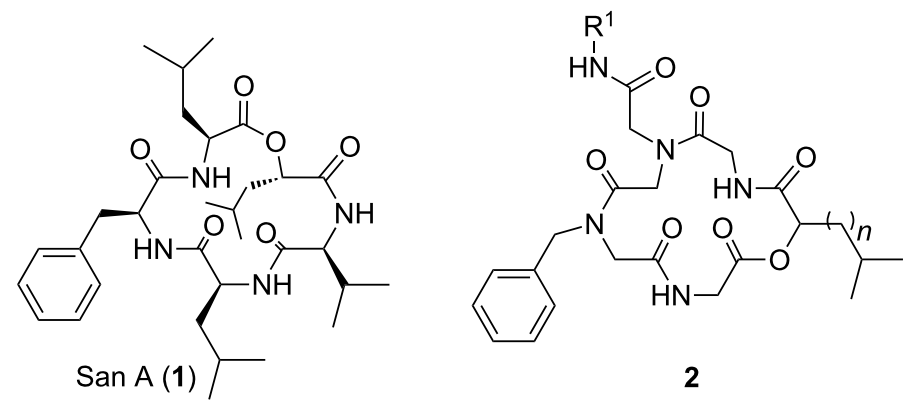

Figure 1: Sansalvamide A (1) and its depsipeptoid analogues (2)

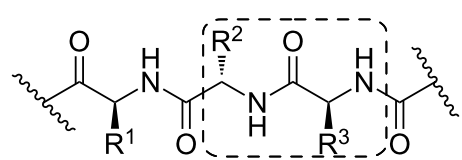

(a) peptide

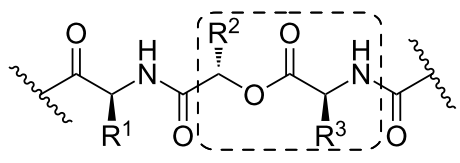

(c) depsipeptide

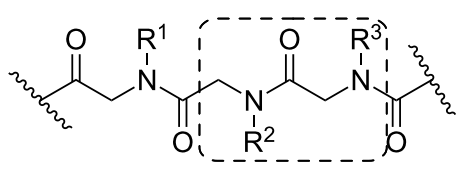

(b) peptoid

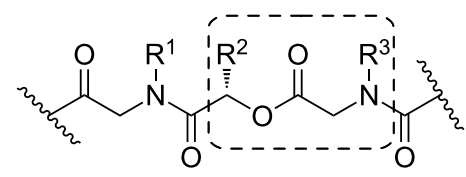

(d) depsipeptoid 


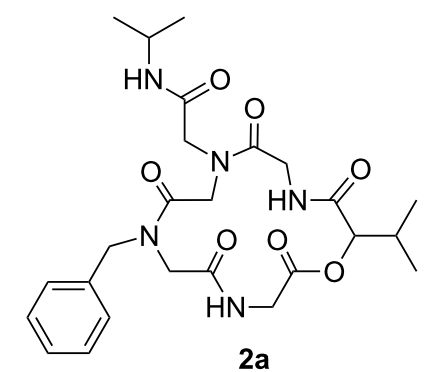<smiles>CC(C)CNC(=O)CN(CC(=O)NCC(=O)N(CC(=O)NCC(=O)O)Cc1ccccc1)C(=O)OC(C(=O)NCC(C)C)C(C)C</smiles><smiles>CC(C)C(OC(=O)CNC(=O)CN(Cc1ccccc1)C(=O)CN(CC(=O)NC(C)(C)C)C(=O)CNC(=O)O)C(C)C</smiles>
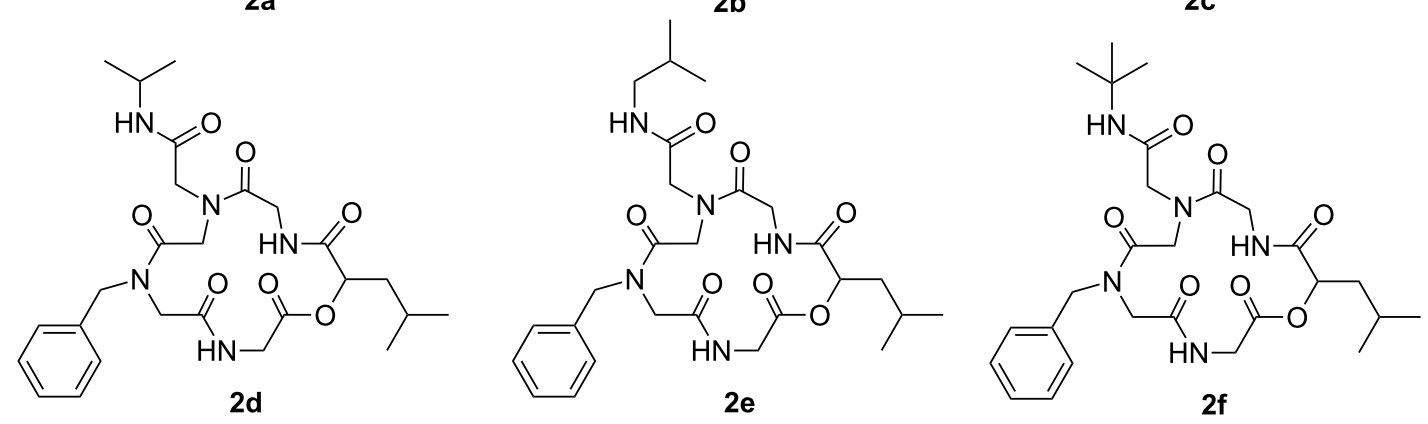

Figure 3: Structures of six pentadepsipeptoid analogues of San A.
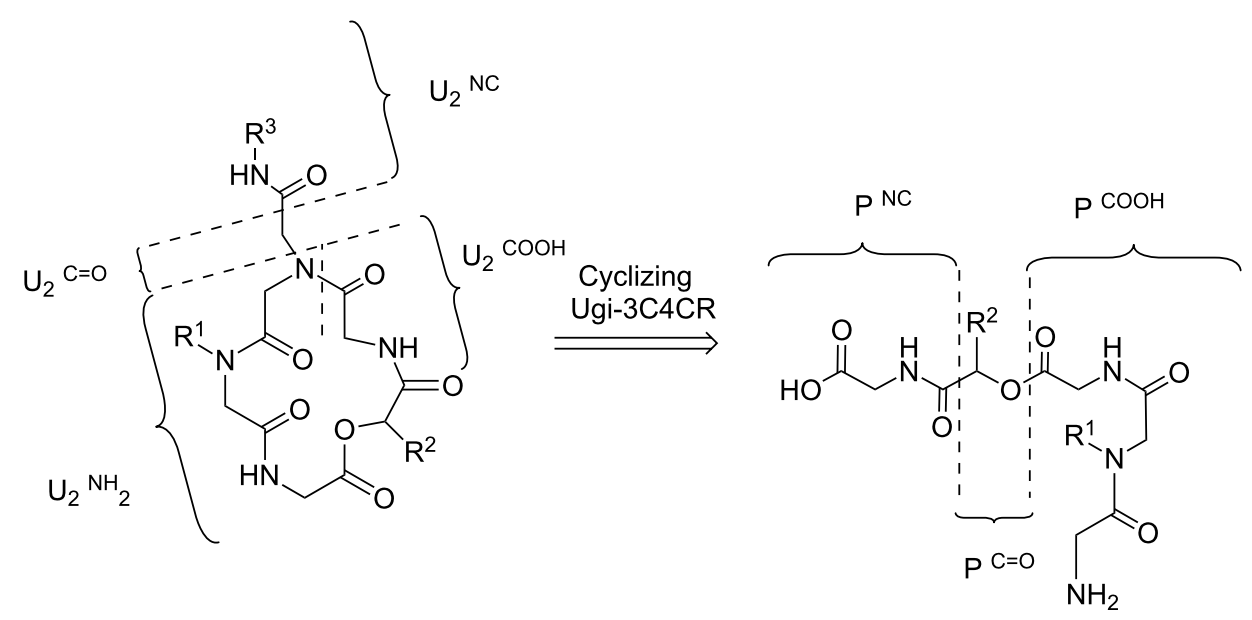

Passerini-3CR

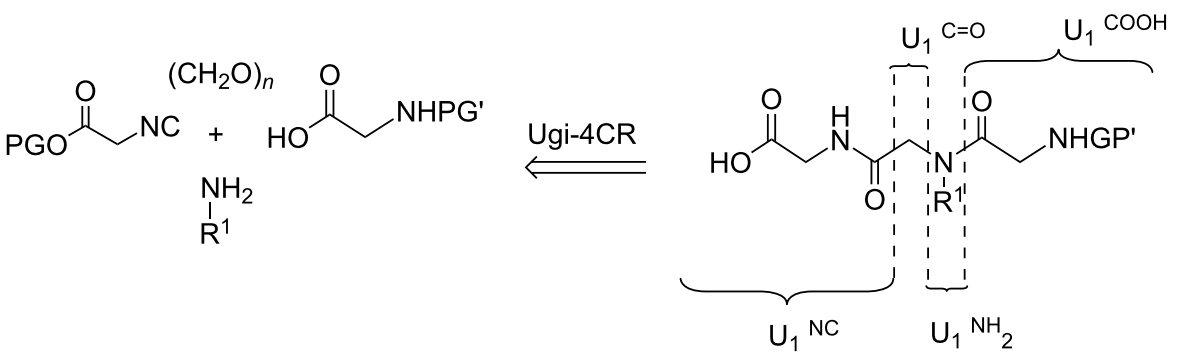


(b) ester hydrolysis; (c) formation of an acyclic depsipeptoid scaffold through a Passerini reaction; (d) deprotection of the amine/acid groups and (e) a macrocyclization step via an intramolecular Ugi reaction.

The general strategy for the synthesis of cyclic pentadepsipeptoids is depicted in Scheme 2. The synthesis of analogues $\mathbf{2}$ was initiated by an Ugi 4-component reaction (U-4CR) using methyl isocyanoacetate (3a), paraformaldehyde (4), benzylamine (5) and $N$-Boc-glycine (6) in $\mathrm{MeOH}$ (Scheme 2 ) in a microwave (MW) reactor $\left(3 \mathrm{~min}\right.$ at $80{ }^{\circ} \mathrm{C}$ ) to provide the peptoid 7 in $77-87 \%$ yield. Peptoid 7 was subjected to hydrolysis in the presence of $\mathrm{LiOH}\left(\mathrm{THF} / \mathrm{H}_{2} \mathrm{O}, 0{ }^{\circ} \mathrm{C}, 2.5 \mathrm{~h}\right)$ followed by treatment with $2 \mathrm{M} \mathrm{NaHSO}_{4}$ providing the corresponding acid 8 in
$92-100 \%$ yield. Acid 8 was then employed in a Passerini reaction with isobutyraldehyde (9a) or isovaleraldehyde (9b) and tert-butyl isocyanoacetate $(\mathbf{3 b})$, in a $\mathrm{MW}$ reactor $(20 \mathrm{~min}$ at $80{ }^{\circ} \mathrm{C}$ ) in THF, affording the acyclic depsipeptoids $\mathbf{1 0 a}$ and $\mathbf{1 0 b}$ in $70 \%$ and $66 \%$ yield, respectively. Removal of the Boc protecting group and ester hydrolysis were achieved after treatment of the acyclic depsipeptoids $\mathbf{1 0 a}, \mathbf{b}$ with TFA in $\mathrm{CH}_{2} \mathrm{Cl}_{2}$, giving the corresponding amino acids $\mathbf{1 1 a}, \mathbf{b}$ as TFA salt in quantitative yields.

In the last step, the depsipeptoid amino acid salts $\mathbf{1 1 a}, \mathbf{b}$ were subjected to an Ugi three-component four-center reaction (U-3C4CR) (Scheme 3). Compounds 11a,b were added under pseudo-high dilution conditions (addition rate: $0.6 \mathrm{~mL} / \mathrm{h}$; addi-

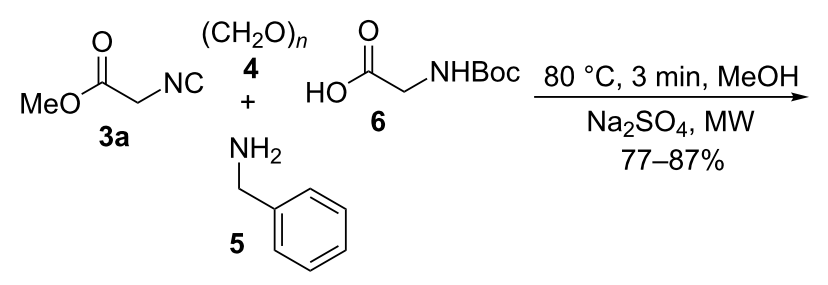<smiles>CCCCNCC(=O)N(CC(=O)NCC(=O)OC)Cc1ccccc1</smiles>

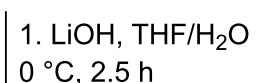
$0{ }^{\circ} \mathrm{C}, 2.5 \mathrm{~h}$<smiles></smiles>

$\frac{1.80^{\circ} \mathrm{C}, 20 \mathrm{~min}, \mathrm{THF}}{\mathrm{MW}}$

10a, $n=0,70 \%$

10b, $n=1,66 \%$

2. TFA/ $/ \mathrm{CH}_{2} \mathrm{Cl}_{2}(1: 4)$

$0{ }^{\circ} \mathrm{C}-\mathrm{rt}, 40 \mathrm{~h}$

$100 \%$ (both)

2. $\mathrm{NaHSO}_{4}(2 \mathrm{M})$<smiles>CC(C)=CC(=O)NCC(=O)N(CC(=O)NCC(=O)O)Cc1ccccc1</smiles>

Scheme 2: Synthesis of acyclic depsipeptoids 11a,b.<smiles></smiles>

11a, $n=0$

11b, $n=1$

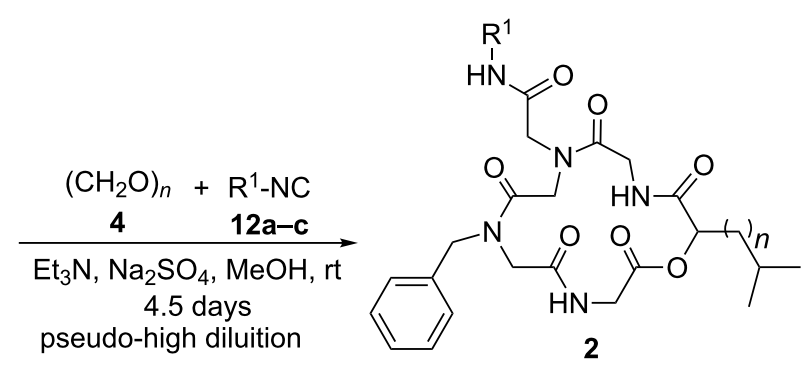

2a: $n=0 ; \mathrm{R}^{1}=$ isopropyl, $33 \%$

2b: $n=0 ; \mathrm{R}^{1}=$ isobutyl, $40 \%$

2c: $n=0 ; \mathrm{R}^{1}=t$-butyl, $49 \%$

2d: $n=1 ; \mathrm{R}^{1}=$ isopropyl, $35 \%$

2e: $n=1 ; \mathrm{R}^{1}=$ isobutyl, $37 \%$

2f: $n=1 ; \mathrm{R}^{1}=t$-butyl, $33 \%$ 
tion time: $83 \mathrm{~h}$; concentration: $0.80 \mathrm{mmol} / \mathrm{L}$ ) to a suspension of paraformaldehyde 4 , triethylamine, sodium sulfate and isopropyl/isobutyl/tert-butyl isocyanide 12a-c in methanol to yield the target cyclic pentadepsipeptoids $\mathbf{2 a}-\mathbf{f}$ after purification by column chromatography (yields ranged from 33-49\% depending on the substrate). The structures of the final products obtained are shown in Figure 3.

\section{Conclusion}

In summary, the approach developed herein allows the synthesis of a wide range of cyclic depsipeptoids. Different structures can be obtained by changes in the amine component in the first Ugi reaction, in the carbonyl component in the Passerini reaction or in the isocyanide and carbonyl components in the macrocyclization step. The general route and procedure developed allows an easy access to complex molecules with a significantly reduced number of steps in short reaction times, and high yields in most of the steps. The strategic combination of two isocyanide-based multicomponent reactions and microwave irradiation makes this a very useful and attractive protocol. The obtained depsipeptoids will be tested for different biological activities.

\section{Supporting Information}

\section{Supporting Information File 1}

General procedures, NMR and mass spectra of all compounds.

[http://www.beilstein-journals.org/bjoc/content/ supplementary/1860-5397-10-101-S1.pdf]

\section{Acknowledgements}

The authors thank the Instituto de Química, Universidade de Brasília, FINEP-CT INFRA n ${ }^{\circ}$ 970/01, CAPES, CNPq, and DAAD for financial support.

\section{References}

1. Wessjohann, L. A.; Andrade, C. K. Z.; Vercillo, O. E.; Rivera, D. G. Targets Heterocycl. Syst. 2006, 10, 24-53.

2. Wessjohann, L. A.; Rhoden, C. R. B.; Rivera, D. G.; Vercillo, O. E. Top. Heterocycl. Chem. 2010, 23, 199-226. doi:10.1007/7081_2009_25

3. Messeguer, J.; Masip, I.; Montolio, M.; del Rio, J. A.; Soriano, E.; Messeguer, A. Tetrahedron 2010, 66, 2444-2454. doi:10.1016/j.tet.2010.01.090

4. Fowler, S. A.; Blackwell, H. E. Org. Biomol. Chem. 2009, 7, 1508-1524. doi:10.1039/b817980h

5. Miller, S. M.; Simon, R. J.; Ng, S.; Zuckermann, R. N.; Kerr, J. M.; Moos, W. H. Bioorg. Med. Chem. Lett. 1994, 4, 2657-2662. doi:10.1016/S0960-894X(01)80691-0
6. Wender, P. A.; Mitchell, D. J.; Pattabiraman, K.; Pelkey, E. T.; Steinman, L.; Rothbard, J. B. Proc. Natl. Acad. Sci. U. S. A. 2000, 97, 13003-13008. doi:10.1073/pnas.97.24.13003

7. Kwon, Y.-U.; Kodadek, T. J. Am. Chem. Soc. 2007, 129, 1508-1509. doi:10.1021/ja0668623

8. Wessjohann, L. A.; Rivera, D. G.; Vercillo, O. E. Chem. Rev. 2009, 109, 796-814. doi:10.1021/cr8003407

9. Dömling, A. Chem. Rev. 2006, 106, 17-89. doi:10.1021/cr0505728

10. Dömling, A.; Wang, W.; Wang, K. Chem. Rev. 2012, 112, 3083-3135. doi:10.1021/cr100233r

11. Dömling, A.; Beck, B.; Eichelberger, U.; Sakamuri, S.; Menon, S.; Chen, Q.-Z.; Lu, Y.; Wessjohann, L. A. Angew. Chem., Int. Ed. 2006, 45, 7235-7239. doi:10.1002/anie.200601259

Erratum: Angew. Chem., Int. Ed. 2007, 46, 2347-2348. doi:10.1002/anie.200790053

12. Pando, O.; Stark, S.; Denkert, A.; Porzel, A.; Preusentanz, R.; Wessjohann, L. J. Am. Chem. Soc. 2011, 133, 7692-7695. doi:10.1021/ja2022027

13. Rivera, D. G.; León, F.; Concepción, O.; Morales, F. E.; Wessjohann, L. A. Chem.-Eur. J. 2013, 19, 6417-6428. doi:10.1002/chem.201201591

14. Neves Filho, R. A. W.; Stark, S.; Westermann, B.; Wessjohann, L. A. Beilstein J. Org. Chem. 2012, 8, 2085-2090. doi:10.3762/bjoc.8.234

15. Barreto, A. F. S.; Vercillo, O. E.; Birkett, M. A.; Caulfied, J. C.; Wessjohann, L. A.; Andrade, C. K. Z. Org. Biomol. Chem. 2011, 9, 5024-5027. doi:10.1039/c1ob05471f

16. Barreto, A. F. S.; Vercillo, O. E.; Andrade, C. K. Z. J. Braz. Chem. Soc. 2011, 22, 462-467. doi:10.1590/S0103-50532011000300008

17. Barreto, A. F. S. Reações Multicomponentes de Isocianetos Consecutivas Assistidas por Micro-ondas: Síntese de Ciclopeptóides e Ciclodepsipeptóides Análogos da Verticilida e Sansalvamida A. Ph.D. Thesis, Universidade de Brasília, Brazil, 2013.

18. Barreto, A. F. S.; Vercillo, O. E.; Wessjohann, L. A.; Andrade, C. K. Z. Blucher Chem. Proc. 2011, 1, 298. http://blucherproceedings.com.br/articles/download/2095

19. Hamel, E.; Covell, D. G. Curr. Med. Chem.: Anti-Cancer Agents 2002, 2, 19-53. doi:10.2174/1568011023354263

20. Belofsky, G. N.; Jensen, P. R.; Fenical, W. T. Tetrahedron Lett. 1999, 40, 2913-2916. doi:10.1016/S0040-4039(99)00393-7

21. Lee, Y.; Silverman, R. B. Org. Lett. 2000, 2, 3743-3746. doi:10.1021/ol0002830

22. Gu, W.; Liu, S.; Silverman, R. B. Org. Lett. 2002, 4, 4171-4174. doi:10.1021/ol0269392

23. Carroll, C. L.; Johnston, J. V. C.; Kekec, A.; Brown, J. D.; Parry, E.; Cajica, J.; Medina, I.; Cook, K. M.; Corral, R.; Pan, P.-S.; McAlpine, S. R. Org. Lett. 2005, 7, 3481-3484. doi:10.1021/ol051161g

24. Liu, S.; Gu, W.; Lo, D.; Ding, X.-Z.; Ujiki, M.; Adrian, T. E.; Soff, G. A.; Silverman, R. B. J. Med. Chem. 2005, 48, 3630-3638. doi:10.1021/jm048952t

25. Otrubova, K.; Styers, T. J.; Pan, P.-S.; Rodriguez, R.; McGuire, K. L.; McAlpine, S. R. Chem. Commun. 2006, 1033-1034. doi:10.1039/b517434a

26. Styers, T. J.; Kekec, A.; Rodriguez, R.; Brown, J. D.; Cajica, J.; Pan, P.-S.; Parry, E.; Carroll, C. L.; Medina, I.; Corral, R.; Lapera, S.; Otrubova, K.; Pan, C.-M.; McGuire, K. L.; McAlpine, S. R. Bioorg. Med. Chem. 2006, 14, 5625-5631. doi:10.1016/j.bmc.2006.04.031 
27. Rodriguez, R.; Pan, P.-S.; Pan, C.-M.; Ravula, S.; Lapera, S.; Singh, E.; Styers, T. J.; Brown, J. D.; Cajica, J.; Parry, E.; Otrubova, K.; McAlpine, S. R. J. Org. Chem. 2007, 72, 1980-2002. doi:10.1021/jo061830j

28. Pan, P.-S.; McGuire, K. L.; McAlpine, S. R. Bioorg. Med. Chem. Lett. 2007, 17, 5072-5077. doi:10.1016/j.bmcl.2007.07.025

29. Davis, M. R.; Styers, T. J.; Rodriguez, R. A.; Pan, P.-S.; Vasko, R. C.; McAlpine, S. R. Org. Lett. 2008, 10, 177-180. doi:10.1021/ol702403r

30. Seebach, D.; Mahajan, Y. R.; Senthilkumar, R.; Rueping, M.; Jaun, B. Chem. Commun. 2002, 1598-1599. doi:10.1039/b204187c

31. Aravinda, S.; Shamala, N.; Das, C.; Balaram, P. Biopolymers 2002, 64, 255-267. doi:10.1002/bip.10192

32. Haque, T. S.; Little, J. C.; Gellman, S. H. J. Am. Chem. Soc. 1996, 118, 6975-6985. doi:10.1021/ja960429j

33. Yang, X.; Wang, M.; Fitzgerald, M. C. Bioorg. Chem. 2004, 32, 438-449. doi:10.1016/j.bioorg.2004.06.011

34. Powers, E. T.; Deechongkit, S.; Kelly, J. W. Adv. Protein Chem. 2005, 72, 39-78. doi:10.1016/S0065-3233(05)72002-7

35. Vasko, R. C.; Rodriguez, R. A.; Cunningham, C. N.; Ardi, V. C.; Agard, D. A.; McAlpine, S. R. ACS Med. Chem. Lett. 2010, 1, 4-8. doi: $10.1021 / \mathrm{ml} 900003 \mathrm{t}$

36. Sellers, R. P.; Alexander, L. D.; Johnson, V. A.; Lin, C.-C.; Savage, J.; Corral, R.; Moss, J.; Slugocki, T. L.; Singh, E. K.; Davis, M. R.; Ravula, S.; Spicer, J. E.; Oelrich, J. L.; Thornquist, A.; Pan, C.-M.; McAlpine, S. R. Bioorg. Med. Chem. 2010, 18, 6822-6856. doi:10.1016/j.bmc.2010.07.042

37. Ardi, V. C.; Alexander, L. D.; Johnson, V. A.; McAlpine, S. R. ACS Chem. Biol. 2011, 6, 1357-1366. doi:10.1021/cb200203m

38. Kunicki, J. B.; Petersen, M. N.; Alexander, L. D.; Ardi, V. C.; McConnell, J. R.; McAlpine, S. R. Bioorg. Med. Chem. Lett. 2011, 21 , 4716-4719. doi:10.1016/j.bmcl.2011.06.083

39. Davis, M. R.; Singh, E. K.; Wahyudi, H.; Alexander, L. D.; Kunicki, J. B.; Nazarova, L. A.; Fairweather, K. A.; Giltrap, A. M.; Jolliffe, K. A.; McAlpine, S. R. Tetrahedron 2012, 68, 1029-1051. doi:10.1016/j.tet.2011.11.089

40. Berłożecki, S.; Szymanski, W.; Ostaszewski, R. Tetrahedron 2008, 64, 9780-9783. doi:10.1016/j.tet.2008.07.064

41. Gulevich, A. V.; Shpilevaya, I. V.; Nenajdenko, V. G. Eur. J. Org. Chem. 2009, 3801-3808. doi:10.1002/ejoc.200900330

42. Leon, F.; Rivera, D. G.; Wessjohann, L. A. J. Org. Chem. 2008, 73, 1762-1767. doi:10.1021/jo7022125

43. Henze, M.; Kreye, O.; Brauch, S.; Nitsche, C.; Naumann, K.; Wessjohann, L. A.; Westermann, B. Synthesis 2010, 2997-3003. doi:10.1055/s-0030-1258182

44. Vercillo, O. E.; Andrade, C. K. Z.; Wessjohann, L. A. Org. Lett. 2008, 10, 205-208. doi:10.1021/ol702521g

45. Neves Filho, R. A. W.; Westermann, B.; Wessjohann, L. A. Beilstein J. Org. Chem. 2011, 7, 1504-1507. doi:10.3762/bjoc.7.175

\section{License and Terms}

This is an Open Access article under the terms of the Creative Commons Attribution License

(http://creativecommons.org/licenses/by/2.0), which permits unrestricted use, distribution, and reproduction in any medium, provided the original work is properly cited.

The license is subject to the Beilstein Journal of Organic Chemistry terms and conditions:

(http://www.beilstein-journals.org/bjoc)

The definitive version of this article is the electronic one which can be found at:

$\underline{\text { doi:10.3762/bjoc. } 10.101}$ 